\title{
SZINTETIKUS SZÁLERŐSÍTÉSÜ BETONOK HOZZÁADOTT TÖRÉSI ENERGIÁJA AZ ADALÉKANYAG FÜGGVÉNYÉBEN
}

\author{
JUHÁSZ KÁROLY PÉTER \\ Laborvezető. BME Szilárdságtani és Tartószerkezeti Tanszék, Czakó Adolf Laboratórium, \\ 1111 Budapest, Müegyetem rkp. 3. K II. 61. Tel.: (36-1) 463-1317. Fax: (36-1) 463-1773. \\ E-mail: juhasz@szt.bme.hu
}

\begin{abstract}
A szálerősítésủ beton egy kompozit anyag, amely betonból, mint a szálak ágyazóanyagából és a benne elkevert szálakból tevődik össze. A beton egy kétfázisú anyag, amely tovább bontható adalékanyag vázra és habarcsra (víz, cement és homok). A beton egy kvázi-rideg anyag, azaz a repedés után rendelkezik maradó húzószilárdsággal, amely a repedéstágasság növekedésével csökken. Ez a maradó feszültség, amely leginkább az adalékanyag függvénye, adja a beton törési energiáját. A hozzákevert szálakkal ez a törési energia megnövelhető. A szálerösítésủ beton törési energiája így két részre bontható: a beton törési energiájára és a szálak által hozzáadott törési energiára. A beton törési energiáját leginkább az adalékanyagok mérete és típusa definiálja, míg a szálak által hozzáadott törési energiát a szál és a habarcs kapcsolata.

A szálak a beton habarcs részével vannak közvetlen kapcsolatban, így felmerül a kérdés, hogy az adalékanyag váznak van-e hatása a hozzáadott törési energiára, vagy attól részben vagy teljesen független. Jelen cikk szintetikus szálerősítésủ betongerendákkal elvégzett kísérletekkel erre a kérdésre keresi a választ.
\end{abstract}

Kulcsszavak: szálerősítésű beton, szintetikus makroszál, törési energia, adalékanyag

\section{BEVEZETÉS}

A beton szálerősítések közül a világ minden területén elsősorban az acél szálerösítések terjedtek el [4]. Ennek ellenére a szintetikus makroszálak néhány évtizedes múltjuk ellenére felveszik a versenyt az acélszállal, köszönhetően az egyik legnagyobb előnyüknek, a teljes korróziómentességnek [16]. A régebbi müszaki elöírások leginkább acél szálerősítésre fókuszálnak [1, 9, 12, 13, 24], az újabbak azonban már tartalmazzák a szintetikus makroszálakat is, mint statikailag figyelembe vehető szálak $[2,20]$.

A méretezésnél a feszültség-megnyúlás diagram definiálásából indulnak ki, amelyet gerendateszt eredményekből származtatnak. Mivel egy berepedt anyagról beszélünk, így a megnyúlás a repedt oldalon csak karakterisztikus hossz mellett értelmezhető [5]. Így a feszültség-megnyúlás átalakítható feszültség-repedéstágasság diagrammá, amely alatti terület a törési energia. A beton törési energiájára az irodalomban számos ajánlást találunk, legtöbb esetben szilárdsági osztály és maximális adalékanyag szemnagyság függvényeként $[8,10]$. Kevés olyan példát találunk, ahol 
a szálerősítésủ betont a törési energia módosításának figyelembevételével modellezik [21], holott kézenfekvő lenne. Felmerül továbbá a kérdés, hogy a megnövekedett törési energia a szál és a beton ismeretében elöre meghatározható-e, illetve minek a függvénye. Szálra és adagolására jellemző hozzáadott törési energiával a szálerősítés nélküli beton törési energiája módosítható lenne, amellyel egy pontos anyagmodellt lehetne definiálni.

Jelen cikkemben abból a feltételezésböl indulok ki, hogy a szálak hozzáadott törési energiája leginkább a szál és a beton kapcsolatának függvénye. Mivel a szál a kétfázisú beton habarcs fázisával érintkezik, így a szál-habarcs kapcsolat definiálja leginkább ezt a hozzáadott törési energiát.

\section{TÖRÉSI ENERGIÁK}

A szálerösítésủ beton a kompozit anyagok csoportjába tartozik, ahol a szálak ágyazóanyaga a beton, a szálak pedig a betonba kevert különféle alakú (pl.: kampós végü, hullámos, bordázott stb.) és anyagú (pl.: acél, üveg, polipropilén stb.) rövid szálak [18]. Az elkeverés során feltételezzük, hogy a szálak véletlenül, de egyenletesen keverednek el a betonban. A beton önmagában is egy kétfázisú anyag, amely a kavicsvázból és a kavicsvázat körülvevő habarcsból (cementpép és homok) áll [3]. A szálak betonnal való kapcsolata a szálak és a habarcs közötti kapcsolattól függ. A szálak anyagát tekintve a húzószilárdságuk nagyobb, mint a beton húzószilárdsága, azonban rugalmassági modulusuk lehet kisebb is, mint a betoné. Az acél rugalmassági modulusa nagyságrendileg $210 \mathrm{GPa}$, a betoné $30-40 \mathrm{GPa}$, míg a szintetikus polipropilén szálaké 8-10 GPa. Ezen különbségek ellenére egyes makroszállal erösített betonok megfelelő adagolás mellett hasonló erő-CMOD (CMOD: Crack Mouth Opening Displacement, bemetszett gerenda alsó felületén a bemetszés megnyílása) görbéket eredményeznek hajlított gerendateszteknél, mint az acélszállal erősített betonok $[16,17]$. Ez több okra vezethető vissza: ugyanakkora maradó feszültség eléréséhez használt szintetikus szálak térfogatszázaléka száltípustól függően nagyságrendileg 2-4-szerese az acélszálénak, tehát több szál dolgozik a berepedt keresztmetszetben [17], illetve más a két szál energiaelnyelése. Míg az acélszálak esetében a feltételezett tönkremenetel az acélszálak kihúzódása a habarcsból [25], addig a szintetikus szálak bordás felületükkel a szál hossza mentén folyamatosan tapadnak a habarcshoz [4], tönkremenetelük a szálak megnyúlása miatti szakadás.

A beton kvázi-rideg anyag, azaz az anyag repedése után a repedés megnyílásának függvényében csökkenő feszültséget tud még felvenni. A feszültség és a repedés megnyílásának függvényét felrajzolva megkapjuk az anyagra jellemző feszültségrepedés tágasság $(\sigma-w)$ összefüggést, e görbe alatti terület a beton törési energiája. A hozzáadott szálak ezt a maradó feszültséget és alakváltozó képességet növelik, növelve így a beton törési energiáját. A különböző típusú szálak a repedéstágasság különböző értékénél fejtik ki elsődleges hatásukat. Nagyobb rugalmassági modulusú 


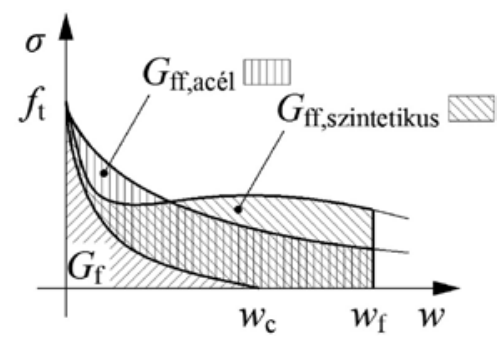

1. ábra. Acél és szintetikus anyagú szálakkal erősített betonok $\sigma-w$ diagramja és a törési energia értelmezése

acélszálak már kis repedéstágasságnál is nagy feszültséget képesek felvenni, a repedéstágasság növekedésével azonban a szálak elszakadnak vagy kihúzódnak a mátrixból [6], csökkentve ezzel a maradó feszültséget. Kis rugalmassági modulusú szintetikus szálak esetében azonban nagyobb megnyúlás alakul ki, mint acélszálak esetében, azaz a szintetikus szálak a nagyobb repedéstágasság esetében is hatékonyan müködnek (1. ábra).

Azt a repedéstágasságot, amelynél a beton repedés felületei között megszünik a feszültség, határ repedésmegnyílásnak (final crack opening width) nevezzük, jele: $w_{\mathrm{c}}$ [21]. Szálerősítésủ betonnál ez az érték jóval nagyobb, méretezési szempontból müszaki elöírásokban megadott értékig mérjük [2, 9, 13, 20, 24]. A szálerősítésü beton így figyelembe vett maximális repedésmegnyílását $w_{\mathrm{f}}$-el jelöljük. A beton törési energiája a betonhoz tartozó feszültség-repedéstágasság diagram alatti terület, jele $G_{\mathrm{f}}$, szálerősítésủ betoné pedig ugyancsak a hozzá tartozó görbe alatti terület, jele $G_{\text {ffRC }}$. A szálak által hozzáadott törési energia ennek a kettőnek a különbsége: azaz $G_{\mathrm{ff}}=G_{\mathrm{fFRC}}-G_{\mathrm{f}}(2 . a ́ b r a)$.

Különböző működésük ellenére mindkét szál energiafelvétele szoros viszonyban van a habarccsal, a beton azon fázisával, amelyikkel ténylegesen érintkezik. Felmerül a kérdés, hogy az adalékváznak van-e hatása a szál okozta törési energia növekményre, azaz a hozzáadott törési energiára, vagy a habarcs és a szál egyértelmủen definiálja azt. Jelen cikkemben szintetikus szálerősítés hozzáadott törési energiáját

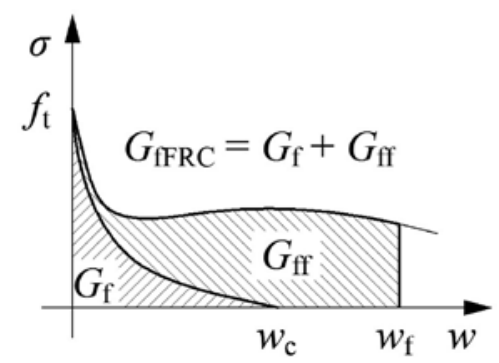

2. ábra. Beton és szálerősítésủ beton törési energiája és a hozzáadott törési energia 
vizsgálom olyan betonok esetében, ahol a habarcs fázis, a szálak típusa és adagolása minden esetben azonos, így a hozzáadott törési energiák változása alapján lehet következtetni az adalékanyagok szerepére.

\section{KÍSÉRLET BEMUTATÁSA}

A kísérlet során olyan betonokat készítettünk, amelyeknél a habarcs és a száladagolás azonos, azonban az adalékanyag változik. Azonos habarcs esetén a habarcs víz/ cement és cement/homok aránya változatlan. Ha a szál törési energiára gyakorolt hatása, azaz a hozzáadott törési energia ezeknél a betonoknál nem változik, akkor a szálak hatása független lesz az adalékanyag méretétől és típusától. Adalékanyagoknál méretbeli, geometriai és szilárdságbeli különbségek hatását is vizsgáltam, ezért a következő 4 féle adalékanyagot választottam: $\mathrm{A}$ jelü beton, $\mathrm{d}_{\max }=4 \mathrm{~mm}$ habarcs; B jelü beton, $\mathrm{d}_{\max }=8 \mathrm{~mm}$ gömbölyü kavics; $\mathbf{C}$ jelü beton, $\mathrm{d}_{\max }=22 \mathrm{~mm}$ zúzott kavics; D jelü beton, $\mathrm{d}_{\max }=16 \mathrm{~mm}$ duzzasztott agyagkavics, könnyü adalékanyag. Az előállított betonok jellemző értékei az 1. táblázatban láthatóak. A cement minden esetben CEM-I 42,5 R volt, míg a víz/cement tényező 0,56 és a cement/homok arány pedig 0,24 , azaz az adalékanyag közötti hézagokat minden esetben ugyanolyan összetételü a habarcs töltötte ki.

A szintetikus szálakból kétfélét választottam (Barchip48 és Barchip54), eltérő adagolással, illetve készült száladagolás nélküli beton is. A kísérletben részt vevő szálak jellemzői és adagolásuk a 2. táblázatban látható.

Minden különböző típusú gerendából 6 darabot készítettem. A gerendákat elkészítésük után vegyesen (14 napig víz alatt, majd 14 napig szárazon) tároltam 28 napos korukig.

1. táblázat. Betonösszetételek

\begin{tabular}{|c|c|c|c|c|c|c|c|c|}
\hline \multirow{2}{*}{$\begin{array}{l}\text { Beton } \\
\text { jele }\end{array}$} & \multirow{2}{*}{ Cement $\mathrm{kg} / \mathrm{m}^{3}$} & \multirow{2}{*}{$\begin{array}{c}\text { Víz } \\
\mathrm{kg} / \mathrm{m}^{3}\end{array}$} & \multicolumn{6}{|c|}{ Adalékanyag kg/m³ } \\
\hline & & & $0 / 4$ & $4 / 8$ & $4 / 11 \mathrm{Z}$ & $11 / 22 \mathrm{Z}$ & $4 / 8 \mathrm{~L}$ & $8 / 16 \mathrm{~L}$ \\
\hline A & 393 & 220 & 1672 & & & & & \\
\hline B & 320 & 180 & 1361 & 478 & & & & \\
\hline $\mathrm{C}$ & 303 & 170 & 1279 & & 301 & 301 & & \\
\hline $\mathrm{D}$ & 285 & 160 & 1192 & & & & 83 & 83 \\
\hline
\end{tabular}

2. táblázat. Szálak jellemzői és adagolásuk

\begin{tabular}{|c|c|c|c|}
\hline Szál jele & Szálhossz, $\mathrm{mm}$ & Szálátmérö, $\mathrm{mm}$ & Szál-darabszám, db/kg \\
\hline $1-\mathrm{BC} 48$ & 48 & $0,5 \times 1,3$ & 60241 \\
\hline $2-\mathrm{BC} 54$ & 54 & $0,4 \times 1,4$ & 35587 \\
\hline
\end{tabular}


3. táblázat. Kísérleti mátrix

\begin{tabular}{|c|c|c|c|}
\hline Gerenda jele & Beton típusa & Szál típusa & $\begin{array}{c}\text { Szál adagolása, } \\
\mathrm{kg} / \mathrm{m}^{3}\end{array}$ \\
\hline A0 & A & - & - \\
\hline A1 & A & 1 & 6 \\
\hline A2 & A & 2 & 4 \\
\hline B0 & B & - & - \\
\hline B1 & B & 1 & 6 \\
\hline B2 & B & 2 & 4 \\
\hline C0 & C & - & 6 \\
\hline C1 & C & 1 & 4 \\
\hline C2 & C & 2 & - \\
\hline D0 & D & - & 6 \\
\hline D1 & D & 1 & 4 \\
\hline D2 & D & 2 & \\
\hline
\end{tabular}

A törési energiák meghatározásához középpontos (hárompontos) gerenda hajlítási vizsgálatot végeztem. A vizsgálatot a RILEM TC 162-TDF [24] irányelvben megjelent ajánlások alapján végeztem el (3. ábra). A kísérletben egy $500 \mathrm{~mm}$ támaszközü kéttámaszú, középen alul $25 \mathrm{~mm}$ mély és $2 \mathrm{~mm}$ széles bevágással gyengített $150 \times 150 \mathrm{~mm}$ keresztmetszetủ gerendát terheltem elmozdulás vezérelt módon 0,2 $\mathrm{mm} /$ perc sebességgel. A mért értékek az erő, középponti lehajlás és a repedésmegnyílás (CMOD) volt. A kísérletet a CMOD $4 \mathrm{~mm}$-es értékéig folytattam. A gerendák

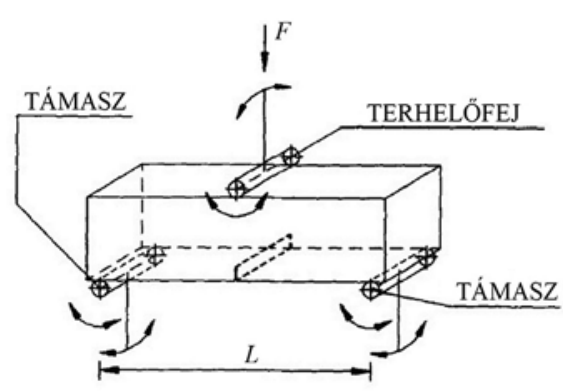

Az egyik támasznak fixnek kell lennie.
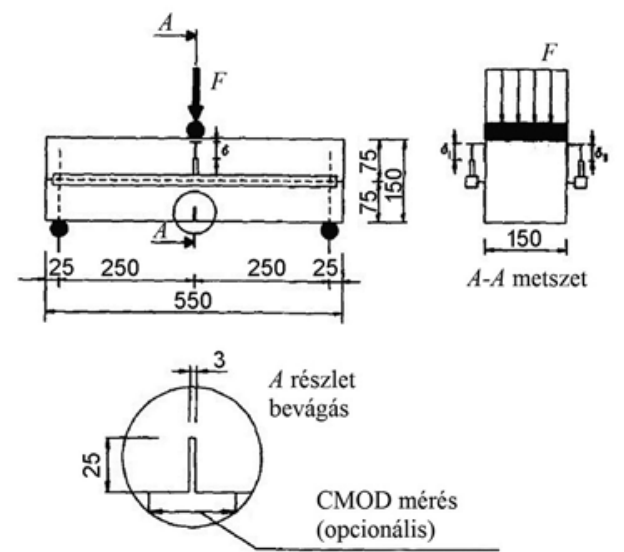

3. ábra. RILEM TC 162-TDF által javasolt hajlítási kísérlet [24] 
és a kísérletsorozat a BME Szilárdságtani és Tartószerkezeti Tanszékének Czakó Adolf Laboratóriumában készültek. Az terhelő berendezés ZWICK/ROELL Z150 típusú univerzális anyagvizsgáló gép volt.

\section{A KÍSÉRLETI EREDMÉNYEK KIÉRTÉKELÉSÉNEK BEMUTATÁSA}

A hajlított gerendavizsgálat egyszerüen elvégezhető kísérlet, ami miatt szabványosítható, iparban a legelterjedtebb vizsgálati módok egyike. Szálerősítésü betongerendák esetén legnagyobb hátránya a magas szórása. Ez a relatív kis méretű referencia felületnek köszönhető, amely itt az átrepedt keresztmetszet: 125×150 mm. Tökéletes elkeveredés feltételezésével a szálak középpontjai azonos távolságra vannak egymástól és a szálak véletlenszerüen, de egyenletesen minden irányban állnak. Ha a szálakat így helyezzük el a beton mátrixban, akkor minden szál középpontja egy térbeli tetraéder hálózat csúcspontján van, amelynek oldalhossza az adagolt szálmennyiség függvénye. Figyelembe véve a szálak hosszát és véletlenszerü orientációját a tetraéder hálózaton elhelyezkedő szálakat egy effektív hosszúságú, de a vizsgált keresztmetszetre merőleges irányú szállal helyettesíthetjük. Ezzel a módszerrel meghatározható az egységnyi keresztmetszeten áthaladó szál darabszám [23]:

$$
n_{\mathrm{a}}=\frac{0,41 \mathrm{Nl}}{V},
$$

ahol:

$n_{\mathrm{a}}$ fajlagos keresztmetszetre eső szálak darabszáma, $\mathrm{db} / \mathrm{mm}^{2}$,

$l \quad$ szálhossz, mm,

$N \quad$ szálak darabszáma a térfogatban,

$V$ térfogat, $\mathrm{mm}^{3}$.

A szálerősítésủ gerendában a szálak miatti repedés után maradó feszültség nagyban függ a szálak keresztmetszeten áthaladó darabszámától, elhelyezkedésétől és orientációjától, így az eredmények pontosságának növelése érdekében a kiértékelés-

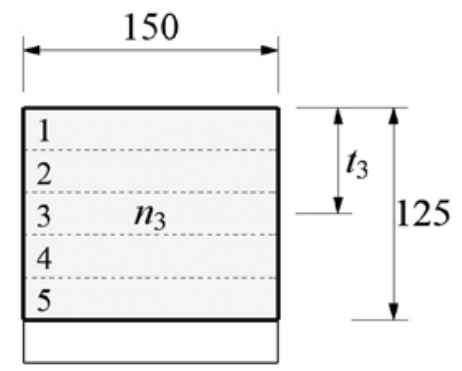

4. ábra. Eltört keresztmetszeten értelmezett sávok és távolságok 
nél a darabszámot és az elhelyezkedést figyelembe vettem [15]. A kísérletre készített gerendákat a hajlítási vizsgálat után félbetörtem, majd a törési felületen áthaladó szálak darabszámát és elhelyezkedését megállapítottam. A szálak elhelyezkedésénél a $125 \times 150 \mathrm{~mm}$-es keresztmetszeti területet 5 darab $25 \times 150 \mathrm{~mm}$-es sávra osztottam (4. ábra), majd minden sávban megszámoltam az elhelyezkedő szálak darabszámát. A szálak elhelyezkedését figyelembe vevő értéket definiáltam: a szálnyomatékot $\left(S_{\mathrm{f}}\right)$, mely a következőképp értelmezhető:

$$
S_{\mathrm{f}}=\sum_{\mathrm{i}=1}^{5} t_{\mathrm{i}} N_{\mathrm{i}},
$$

ahol:

$S_{\mathrm{f}} \quad$ szálnyomaték, mm,

$t_{\mathrm{i}} \quad$ szálmezők középpontjának távolsága a semleges tengelytől, közelítésképp a gerenda szélső szálától, mm (4. ábra),

$N_{\mathrm{i}} \quad$ szálak darabszáma az aktuális mezőben.

A szálnyomatékra leginkább a szálak semleges tengelytől vett távolsága van hatással, a keresztmetszet szélessége mentén való elhelyezkedés így a kísérlet szempontjából érdektelen. A nyomott betonzóna vastagsága mind számítások, mind kísérleti megfigyelések alapján a gerenda magasságához viszonyítva elhanyagolhatóan kicsi, így a semleges tengelyt a gerenda szélső szálára helyeztem.

A törési felületen áthaladó szálak darabszáma tökéletes elkeveredést feltételezve az (1)-ből számítható, majd ebből a hozzá tartozó szálnyomaték $\left(S_{\mathrm{f}, \mathrm{m}}\right)$ kapható meg (3). Továbbiakban ezt tekintjük az ideális szálnyomatéknak.

$$
S_{\mathrm{f}, \mathrm{m}}=\frac{125}{2} A n_{\mathrm{a}} \text {, }
$$

ahol:

$S_{\mathrm{f}, \mathrm{m}} \quad$ tökéletes elkeveredéshez tartozó szálnyomaték, ideális szálnyomaték, mm, $A$ törési keresztmetszet területe $\left(150 \times 125 \mathrm{~mm}^{2}\right)$,

$n_{\mathrm{a}} \quad$ fajlagos keresztmetszetre eső szálak darabszáma, $\mathrm{db} / \mathrm{mm}^{2}$.

Az egyes vizsgálatokat az erö-CMOD görbéjük és a szálnyomatékuk alapján jellemezhetjük. Az ideális szálnyomaték segítségével a tökéletes elkeveredéshez tartozó görbére következtethetünk. A görbe jellemzésére a görbe alatti területet használom, amely egy munkát ad meg $\left(W_{\mathrm{f}}\right)$, számszerüsítve ezzel a szálak betonban végzett munkáját. Az ideális szálnyomatékkal ugyancsak meghatározhatjuk az ideális munkát is $\left(W_{\mathrm{f}, \mathrm{m}}\right)$. Ennek a meghatározásához az egyes szálnyomatékokhoz tartozó munkákat grafikonon ábrázoljuk, majd lineáris regresszióval egyenest illesztünk az adatokra. A regressziós egyenes ideális szálnyomatékhoz tartozó értékét tekintjük a kísérletek összehasonlítási alapjának, az ideális munkának (5. ábra). 


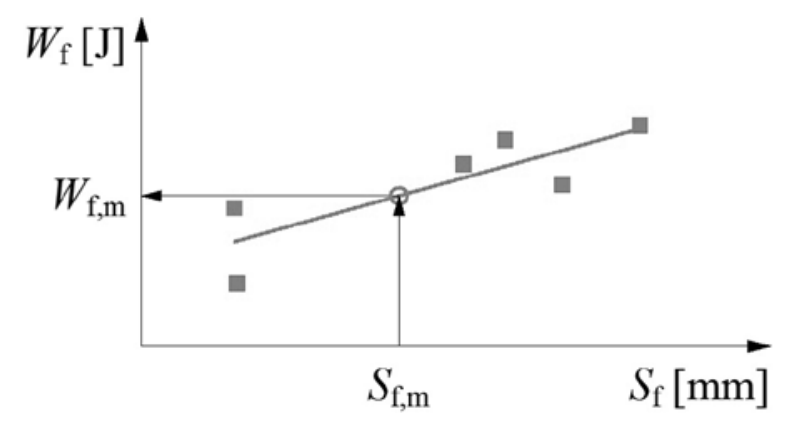

5. ábra. Az ideális munka meghatározása

Az erö-CMOD diagramokból inverz analízis segítségével meghatározható a törési energia [19]. Az inverz analízis során ATENA végeselem programmal modelleztem a gerendákat, majd meghatároztam a numerikus erö-CMOD diagramokat. Ezeket a numerikus diagramokat hasonlítottam össze a kísérleti eredményekkel. Az anyagmodell törési energiáját úgy állítottam be, hogy a két görbe a legjobban illeszkedjen egymásra. Elöször a szál nélküli betongerendák törési energiáját határoztam meg $\left(G_{\mathrm{f}}\right)$, amelyhez Hordijk ajánlotta exponenciális feszültség-repedéstágasság görbét vettem alapul [11]. A szálerősítésü betonok törési energiáját $\left(G_{\mathrm{fFRC}}\right) w_{\mathrm{f}}=3,3 \mathrm{~mm}$ repedéstágassági értékig vettem figyelembe, amely megfelel a $4 \mathrm{~mm}$-es CMOD értékhez tartozó repedésmegnyílásnak. A szintetikus szálak esetében a repedés utáni maradó feszültség nagyjából állandó értéket vesz fel [7], így a modellezés során ezt a feszültséget egy állandó értékkel közelítettem: $f_{\mathrm{f}}$. Az így felvett anyagmodellel numerikusan meghatároztam az erö-CMOD diagramot, majd ezen diagram alatti területet: $W_{\mathrm{f}, \text { num }}$. Iterációval megkerestem azt az $f_{\mathrm{f}}$ értéket, amelynél $W_{\mathrm{f}, \text { num }}=W_{\mathrm{f}, \mathrm{m}} \cdot \mathrm{Az}$ így kapott $f_{\mathrm{f}}$ értékkel és a beton törési energiáival a feszültség-repedéstágasság diagramok felrajzolhatóak, azokból pedig a törési energiák meghatározhatóak (6. ábra).

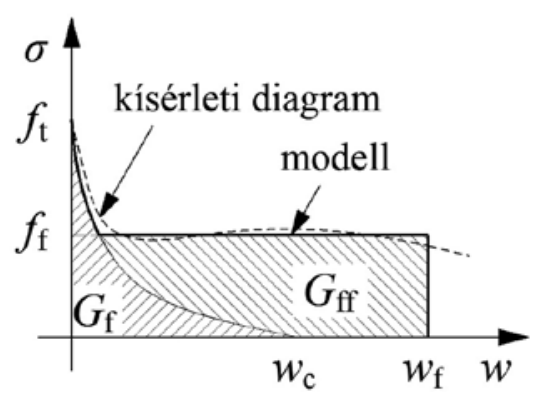

6. ábra. Numerikus modellnél alkalmazott törési energiák 


\section{KÍSÉRLETI EREDMÉNYEK ÉRTÉKELÉSE}

A betonok és szálerösítésủ betonok törési energiája, illetve a hozzáadott törési energia értékeit a 4. táblázatban foglaltam össze.

A szálerősítés nélküli betonok közül a legalacsonyabb törési energiája a duzzasztott agyagkaviccsal készült $\mathbf{D}$ jelü betonnak volt, majd azt követte az $\mathbf{A}$ jelü habarcs, végül pedig a $\mathbf{B}$ és $\mathbf{C}$ jelü beton. Ugyanezen szálerősítés nélküli betonok nyomó-, illetve hajlító-húzószilárdságának sorrendje másképp alakult: a legalacsonyabb értéket itt is a $\mathbf{D}$ jelü beton érte el, majd a $\mathbf{B}$ jelü beton következett, végül az $\mathbf{A}$ jelü habarcs és a $\mathbf{C}$ jelü beton. A habarcs nyomószilárdsága tehát nagyobb volt, mint a kisméretü kaviccsal készült betoné. A nyomó- és hajlító-húzószilárdságok egymáshoz képest a vártnak megfelelően alakultak: alacsonyabb nyomószilárdsághoz alacsonyabb hajlító-húzószilárdság párosult (7.a ábra). A szálerősítés hozzáadásával

4. táblázat. Beton és szálerösítésủ beton törési energiája, hozzáadott törési energia

\begin{tabular}{|c|c|c|c|c|}
\hline Szál jele & Beton jele & $\begin{array}{c}\text { Beton törési energiája, } \\
G_{\mathrm{f}}[\mathrm{N} / \mathrm{mm}]\end{array}$ & $\begin{array}{c}\text { FRC törési energiája, } \\
G_{\text {frRC }}[\mathrm{N} / \mathrm{mm}]\end{array}$ & $\begin{array}{c}\text { Hozzáadott törési energia, } \\
G_{\mathrm{ff}}[\mathrm{N} / \mathrm{mm}]\end{array}$ \\
\hline 1 & A & 0,110 & 2,249 & 2,139 \\
\hline 1 & B & 0,130 & 2,440 & 2,31 \\
\hline 1 & C & 0,160 & 2,392 & 2,232 \\
\hline 1 & D & 0,098 & 1,892 & 1,794 \\
\hline 2 & A & 0,110 & 1,076 & 0,966 \\
\hline 2 & B & 0,130 & 1,318 & 1,188 \\
\hline 2 & C & 0,160 & 1,384 & 1,224 \\
\hline 2 & D & 0,098 & 0,870 & 0,772 \\
\hline
\end{tabular}

b)

a)

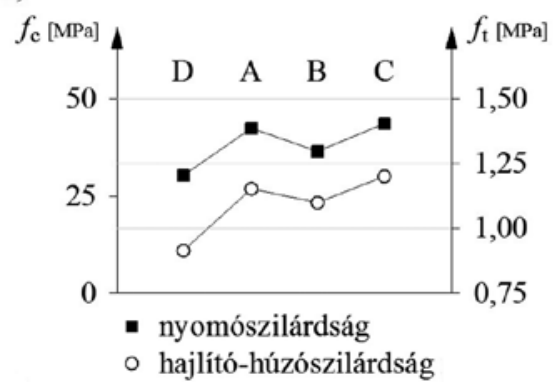

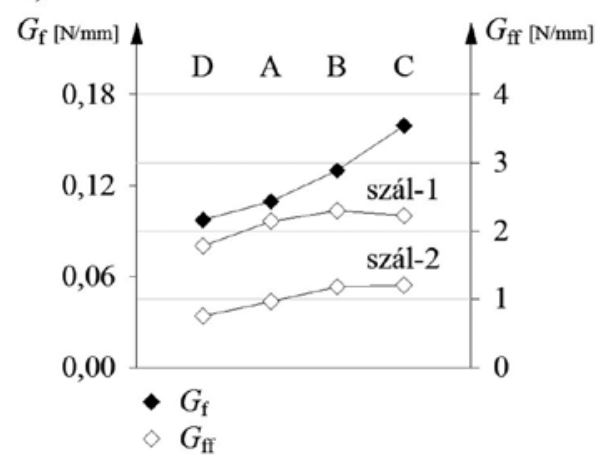

7. ábra. a) Szálnélküli beton nyomó- és hajlító-húzószilárdsága $[\mathrm{MPa}]$; b) Beton törési energiája $\left(G_{\mathrm{f}}\right)$ és szálerösítésü beton hozzáadott törési energiája $\left(G_{\mathrm{ff}}\right)[\mathrm{N} / \mathrm{mm}]$ 
sem a nyomó, sem a hajlító-húzószilárdság nem változott számottevően, amely kis adagolásnál megfelel az irodalomban fellelhető adatoknak [22].

A szálerősítésü betonok hozzáadott törési energiája hasonló módon változik, mint a szálerősítés nélküli betonok törési energiája, azonban a beton nyomó-, illetve hajlító-húzószilárdságával nem mutattak összefüggést (7. ábra).

A B és C jelü kavicsbetonoknál a hozzáadott törési energiák változása 4\%-on belül maradt, habár a betonok törési energiája ezeknél a betonoknál változott a legnagyobb mértékben: a $\mathbf{C}$ jelü beton törési energiája $23 \%$-kal volt nagyobb, mint a $\mathbf{B}$ jelü betoné. Nyomószilárdságban mintegy $20 \%$-ot növekedett a $\mathbf{C}$ jelü beton a $\mathbf{B}$ jelü betonhoz képest. Ez alapján megállapítható, hogy a vizsgált esetben a hozzáadott törési energia kavicsbetonok esetében leginkább a habarcsösszetétel függvénye, az adalékanyag mérete és típusa kis hatással van csak rá. Ugyanakkor az adalékanyagok jelentős mértékben változtatják a betonok nyomó- és hajlító-húzószilárdságát, illetve törési energiáját.

Az A jelü habarcsnál és a $\mathbf{D}$ jelü könnyübetonnál azonban mind a betonok törési energiájának, mind a szálerősítésü betonok hozzáadott törési energiájának a növekménye $18 \%$ feletti volt. Összehasonlítva $\mathbf{C}$ jelủ zúzott kavicsbeton törési energiája mintegy 63\%-kal volt nagyobb, mint a $\mathbf{D}$ jelü könnyübetoné, hozzáadott törési energiája pedig rendre 24 , illetve $58 \%$-kal volt nagyobb az 1-es és 2 -es szálerösítés esetében.

\section{ÖSSZEFOGLALÁS}

A kísérleti eredmények alapján több megállapítás tehető.

I. A kavicsbetonok esetében a szálak miatti hozzáadott törési energia leginkább a habarcsösszetétel, nem pedig a nyomószilárdság függvénye: a hozzáadott törési energia változása 4\%-on belül maradt, míg a nyomószilárdságban mintegy $20 \%$-os eltérés volt a $d_{\max }=8$ és $d_{\max }=22 \mathrm{~mm}$ maximális szemnagyságú betonoknál;

II. A habarcs, illetve könnyübeton esetében azonban mind a törési energiák, mind a betonszilárdságok jelentős mértékben változtak, mégpedig a nyomószilárdság csökkenésével egyenes arányban.

A szálak hozzáadott törési energiája kavicsbetonok esetében a habarcs víz/cement és cement/homok arányának függvényében megadható érték, amely segítségével szálerősítésű beton anyagmodell definiálható. Nyomószilárdság függvényében megadott maradó feszültség, illetve hozzáadott törési energia nem kellően pontosan definiálja az anyagmodellt. Ugyanazon nyomószilárdság kisméretü, gömbölyü szemü kavicsokkal készült beton esetében csak kisebb víz/cement tényezővel érhető el a nagyobb méretü, zúzott kavicsokkal készült betonhoz képest. Ez a kisebb víz/cement tényező pedig más habarcsot eredményez, amelyben a szálak másképp müködnek. Azonban ha a habarcs összetétele azonos, a hozzáadott törési energia is azonos lesz és független az alkalmazott kavicsváztól.

Habarcs és könnyübeton esetében azonban ez az összefüggés nem áll fenn, minden esetben kisebb hozzáadott törési energia értéket eredményezett a kavicsbetonhoz 
képest. Minél kisebb az alkalmazott adalékanyag szemcseszilárdsága, annál kisebb a törési energia, s vele együtt a hozzáadott törési energia is.

A szálerősítésủ betont, mint kompozit anyagot, különböző anyagparaméterekkel jellemezhetjük. A hozzáadott szintetikus makroszálak az anyag nyomó-, illetve hajlító-húzószilárdságát kismértékben változtatják meg, legnagyobb hatásuk a repedés utáni maradó feszültségre, illetve törési energiára van. Kísérleteim szerint kavicsbetonok esetében a szálak által megnövelt törési energia azonos habarcsösszetétel, de különböző kavicsváz esetében nem változik. Kavicsváz nélküli habarcs, illetve könynyü adalékanyaggal készült betonoknál ugyanazon habarcsösszetétel mellett ez az összefüggés már nem áll fenn. Mivel a szálak hatását sok paraméter befolyásolja, így a nyomószilárdsághoz megadott szálra jellemző anyagparaméterek csak közelítő értékként használhatóak. Pontos számításhoz nem elegendő a beton szilárdsági osztályának az ismerete, fontos tudni a habarcs összetételét, illetve az alkalmazott adalékanyag típusát és méretét is. A hozzáadott energiára még a beton törési energiájából sem tudunk egyértelmüen következtetni. Nagy jelentőséggel bíró szerkezet tervezésénél így minden esetben a betontechnológiai tervezés után gerendavizsgálatokkal kell a szálerősítésủ beton kompozit anyagparamétereit kimérni.

\section{KÖSZÖNETNYILVÁNÍTÁS}

A szerző itt szeretne köszönetet mondani a betongerendák elkészítésében nyújtott nagy segítségért Óvári Vilmos betontechnológusnak és a Czakó Adolf Laboratórium technikusának, Sebestyén Ottónak. A cementet a Duna-Dráva Cement Kft. szolgáltatta, az adalékanyagokat pedig a York bánya. A kísérletekhez használt ZWICK/ ROELL Z150 típusú univerzális anyagvizsgáló gépet a TÁMOP 4.2.1/B-09/1/KMR2010-0002 pályázat biztosította.

\section{HIVATKOZÁSOK}

[1] ACI Committee 544: Design Considerations for Steel Fibre Reinforced Concrete. ACI 544.4R-88, 1999.

[2] Advisory Committee on Technical Recommendations for Construction: CNR-DT 204/2006: Guide for the Design and Construction of Fibre-Reinforced Concrete Structures. Advisory Committee on Technical Recommendations for Construction, Rome 2006.

[3] Balázs Gy.: Különleges betonok és betontechnológiák I. Akadémia Kiadó, Budapest 2007.

[4] Balázs L. Gy. - Polgár L.: A szálerősítésű betonok múltja, jelene és jövője. In: Szálerősitésü Betonok - a kutatástól az alkalmazásig. Budapest 1999. 1-23.

[5] Bazant, Z. P. - Oh, B. H.: Crack Band Theory for Fracture of Concrete. Materials and Structures 16 (1984) 155-177.

[6] Bernard, E. S.: Embrittlement of Fibre-Reinforced Shotcrete. Shotcrete 10 (2008) 16-21.

[7] Bernard, E. S.: Design of fibre reinforced shotcrete linings with macro-synthetic fibres. In: 2009 ECI Conference on Shotcrete for Underground Support XI, paper 14. 
[8] CEB-FIP Model Code 1990. Design code, CEB Bulletin d'information No 213/214, Thomas Telford Services Ltd., $437 \mathrm{pp}$.

[9] DBV (German Concrete and Construction Technology Association): DBV-steel fibre reinforced concrete, Deutscher Beton- und Betontechnik-Verein EV, 2001.

[10] Hilsdorf, H. K. - Brameshuber, W.: Code-type formulation of fracture mechanics concepts for concrete. International Journal of Fracture Vol. 51, pp. 61-72.

[11] Hordijk, D. A.: Local Approach to Fatigue of Concrete. Doktori disszertáció. Delft University of Technology, Hollandia 1991.

[12] International Federation for Structural Concrete (fib): Model Code 2010 (Final Version), fib Bulletins 65 \& 66, Lausanne 2012.

[13] Japan Society of Civil Engineers: Method of test for flexural strength and flexural toughness of SFRC, Standard JSCE SF-4 (1985).

[14] Juhász, K. P.: Modified fracture energy method for fibre reinforced concrete. In: Fibre Concrete 2013: Technology, Design, Application. Prága 2013. 89-90.

[15] Juhász K. P.: Szintetikus makro szálerősítésű beton gerendavizsgálatok kiértékelése a valós száleloszlás vizsgálata alapján. Anyagvizsgálók lapja (2013) 3-4. 93-97.

[16] Juhász K. P.: Mikro és makro szintetikus szálakkal készített beton próbatestek vizsgálata. Épités Épitészettudomány 42 (2014) 1-2. 57-71.

[17] Juhász K. P.: Szintetikus makro szálerősítésü betonok. Diplomamunka feladat, Betontechnológia Szakirányú Továbbképzés, BME Építőanyagok és Mérnökgeológia Tanszék 2014.

[18] Kollár, L. P. - Springer, G. S.: Mechanics of composite structures. Cambridge University Press, Cambridge 2003.

[19] Meskenas, A. et al.: Inverse analysis technique for determination of residual stress-crack opening relationship of SFRC. In: Fibre Concrete 2013: Technology, Design, Application. Prága 2013. 39 40.

[20] Österreichische Vereinigung für Beton- und Bautechnik: Richtlinie Faserbeton. Österreichische Vereinigung für Beton- und Bautechnik, Wien 2008.

[21] Park, K. - Paulino, G. H. - Roesler, J.: Cohesive fracture model for functionally graded fibre reinforced concrete. Cement and Concrete Research 40 (2010) 956-965.

[22] Romualdi, J. P. - Batson, G. B.: Tensile strength of concrete affected by uniformly distributed beams with closely spaced reinforcement. ACI Journal 60 (1963) 6. 775-790.

[23] Romualdi, J. P. - Mandel, J. A.: Tensile Strength of Concrete Affected by Uniformly Distributed and Closely Spaced Short Lengths of Wire Reinforcement. ACI Journal 61 (1964) 6. 657-672.

[24] Vandewalle, L. et al.: RILEM TC 162-TDF : Test and design methods for steel fibre reinforced concrete. Materials and Structures Vol. 33 (2002), January-February, 3-5.

[25] Voo, J. Y. L. - Foster, S. J.: Variable Engagement Model for Fibre Reinforced Concrete in Tension. Uniciv Report No. R-420, School of Civil and Environmental Engineering, The University of New South Wales, Sydney, NSW, Australia 2003.

\title{
ADDED FRACTURE ENERGY \\ OF THE SYNTHETIC FIBRE REINFORCED CONCRETE AS A FUNCTION OF THE AGGREGATE
}

\begin{abstract}
Summary
The fibre reinforced concrete (FRC) in question is a composite material, which consists of concrete as the bedding material of the fibres and distributed fibres. The concrete itself is a bi-component material: consisting of aggregate frame filled by cement grout (water, cement and sand). The concrete is a quasi-brittle material which has a residual tension strength after crack, decreasing to zero during crack
\end{abstract}


opening. This residual tension strength is mostly the function of the aggregate and it produces the fracture energy. This fracture energy could be increased by added fibres. The fracture energy of the FRC could be divided to two parts: fracture energy of the plain concrete and added fracture energy by the fibres. The fracture energy of the concrete mostly depends on the size and type of the aggregates, while the added fracture energy depends on the connection of the fibres and the cement grout.

The fibres are connecting directly to the cement grout, so the question arises: do the aggregate has any influence on the added fracture energy, or is it partially or totally independent from that. In this article the answer is researched by series of synthetic fibre reinforced bending beam tests.

Keywords: fibre reinforced concrete, synthetic macro fibre, fracture energy, aggregate 